\title{
Evaluation of a modified method to measure total starch in animal feeds
}

\author{
${ }_{3}$ Q1 Sanjeewa D. Ranathunga*, Kenneth F. Kalscheur ${ }^{1}$, Jill L. Anderson, Kevin J. \\ Herrick $^{2}$
}

5 Q2 Dairy and Food Science Department, South Dakota State University, Brookings, SD 57007, USA

\section{A R T I C L E I N F O}

\section{Article history:}

Received 13 October 2016

Received in revised form 19 January 2017

Accepted 27 January 2017

Available online $\mathrm{xxx}$

\section{Keywords:}

AOAC Method 996.11

Total starch

Feed analysis

Enzymatic

\begin{abstract}
A B S T R A C T
The AOAC method 996.11 (AOAC, 2005) has been recognized as an accurate, repeatable, and efficient method to measure total starch in animal feeds. However, analyzing starch using the AOAC method can be expensive and associated with technical challenges. The objectives of this study were to determine if an alternative modified starch method (MAOAC) could be more economical and minimize technical challenges associated with the AOAC method. Modification of the AOAC method, 996.11 (AOAC, 2005) was done by combining the AOAC method with the acetate buffer method of Hall (2009) and introducing alpha-amylase (1162 liquefon units/assay) and amyloglucosidase (400 units/assay) from different sources (ANKOM Technology Inc., Macedon, NY and Sigma-Aldrich Inc., St. Louis, MO). Dried rumen and fecal samples, alfalfa hay, dried distillers grains with solubles, corn silage, total mixed ration (TMR), concentrate mixture, ground corn, and pure corn starch were analyzed using the AOAC and MAOAC methods. Two technicians performed two runs of each method and all samples were analyzed in duplicate within each run. The average starch concentration for 9 samples was not affected by method (AOAC method $=298.7 \pm 1.84 ;$ MAOAC $=298.0 \pm 1.39 \mathrm{~g} / \mathrm{kg} ; P=0.49$ ), technician (technician $\mathrm{I}=297.8 \pm 12.8 \mathrm{~g} / \mathrm{kg}$; technician $\mathrm{II}=299.0 \pm 19.6 \mathrm{~g} / \mathrm{kg} ; P=0.24$ ), or run (run I $=298.4 \pm 15.3 \mathrm{~g} / \mathrm{kg}$; run $\mathrm{II}=298.1 \pm 17.0 \mathrm{~g} / \mathrm{kg} ; P=0.59$ ). The average time spent to analyze 18 assays was approximately $3 \mathrm{~h}$ for both methods. Average chemical cost per assay with the MAOAC method was $\$ 0.88$ compared with $\$ 3.41$ for the AOAC method. There was a $79 \%$ decrease in water consumption for the samples containing $>100 \mathrm{~g} / \mathrm{kg}$ starch with the MAOAC method compared with the AOAC method. The MAOAC starch assay could be considered a cost-effective, more environmentally friendly, and less technically difficult method compared with the AOAC starch method.
\end{abstract}

(c) 2017 Elsevier B.V. All rights reserved.

\footnotetext{
Abbreviations: AOAC method, Association of Official Analytical Chemists method; MAOAC method, modified Association of Official Analytical Chemists method; TMR, total mixed ration; DMSO, dimethyl sulfoxide; GOPOD, glucose oxidase-peroxidase-aminoantipyrine buffer mixture.

* Corresponding author. Present address: Department of Dairy Science, University of Wisconsin-Madison, 1675, Observatory Dr., Madison, WI 53706, USA.

E-mail address: sanjeewadilranathunga@gmail.com (S.D. Ranathunga).

1 Present address: USDA-Agricultural Research Service, U.S. Dairy Forage Research Center, 1925 Linden Dr., Madison, WI 53706, USA.

2 Present address: POET Nutrition, 4506 N. Lewis Ave, Sioux Falls, SD 57104, USA.
} 


\section{Introduction}

Starch is a major source of energy in livestock diets. However, elevated dietary starch may cause undesirable effects on glycemic response and animal health measures, such as ruminal acidosis (Hall, 2009). Accordingly, accurate measurement of starch is important for diet formulations and digestibility evaluation of animal feeds.

Over the last few decades, various chemical and enzymatic methods have been introduced to measure total starch in animal feeds (Moreels and Amylum, 1987). However, the lack of specificity and the use of corrosive and dangerous chemicals have caused chemical methods to become less popular compared with enzymatic methods. Furthermore, the availability of amylases from various sources has resulted in a proliferation of enzymatic methods to analyze starch (Karkalas, 1985). These methods vary in ease of use, time spent on analysis, and cost per assay.

The AOAC Official starch method 996.11 (AOAC, 2005) was developed by McCleary et al. (1997). This method is a quantitative and reliable total starch assay using thermostable $\alpha$-amylase and amyloglucosidase which allows for measurement of total starch concentration in a wide range of food, feed, plant, and cereal products. In this method, samples that contain minimal concentrations of resistant starch are incubated at $100 \bigcirc \mathrm{C}$ with thermostable alpha-amylase followed by amyloglucosidase which allows for hydrolysis to glucose. Samples that contain large concentrations of resistant starch are completely solubilized by pretreatment with dimethyl sulfoxide (DMSO) at $100^{\circ} \mathrm{C}$, followed by thermostable alpha-amylase treatment. The resulting maltodextrins are hydrolyzed to glucose with amyloglucosidase, and the glucose is measured using glucose oxidase/peroxidase reagent. This method has been recognized as an accurate, repeatable, and efficient method to measure total starch; however, the method can be expensive and associated with technical challenges.

An acetate buffer method was introduced to determine dietary starch in animal feeds by Hall. This method is a modification of the assay developed by Bach Knudsen (1997) and introduced techniques to avoid known technical defects that decrease the accuracy of other starch assays (Hall, 2009). However, this method requires approximately $5 \mathrm{~h}$ to complete and is time consuming. Therefore, the objectives of this study were to determine if an alternative starch method would be more economical and could minimize technical challenges associated with AOAC method 996.11 (AOAC, 2005).

\section{Materials and methods}

\subsection{Materials}

Total Starch Assay Kits were purchased from Megazyme International Ireland Ltd. (Wicklow, Ireland). Thermostable $\alpha-$ amylase from Bacillus licheniformis was purchased from ANKOM Technology Inc. (Macedon, NY). All other chemicals and reagents were purchased from Sigma-Aldrich Inc. (St. Louis, MO).

Samples of (1) rumen contents; (2) fecal samples; (3) alfalfa hay; (4) dried distillers grains with solubles; (5) corn silage; (6) total mixed ration (TMR) for lactating dairy cows; (7) concentrate mixture for lactating dairy cows; (8) dry ground corn; and (9) pure corn starch were analyzed for total starch concentrations. All feed, rumen, and fecal samples were collected at the South Dakota State University Dairy Research and Teaching Facility. Pure corn starch was purchased from Megazyme International Ireland Ltd. (Wicklow, Ireland). All samples with the exception of pure corn starch were dried at $55^{\circ} \mathrm{C}$ for $48 \mathrm{~h}$ in a Despatch oven (style V-23, Despatch Oven Co., Minneapolis, MN). The dried samples were ground to a 4-mm particle size (Wiley mill, model 3; Arthur H. Thomas Co., Philadelphia, PA) and then further ground to 1-mm particle size using an ultracentrifuge mill (Brinkman Instruments Co., Westbury, NY). Ground samples were analyzed for DM which was determined at $105^{\circ} \mathrm{C}$ for $3 \mathrm{~h}$ (Shreve et al., 2006). All samples, except the pure corn starch sample, were further ground to pass $0.5-\mathrm{mm}$ screen using an ultracentrifuge mill (Brinkman Instruments Co., Westbury, NY) before the starch analysis.

\subsection{Experimental design}

The modification of the AOAC method was done by combining the AOAC method 996.11 (AOAC, 2005) with the acetate buffer method by Hall (2009) and using $\alpha$-amylase (EC 3.2.1.1; ANKOM Technology Inc., Macedon, NY), amyloglucosidase (EC 3.2.1.3), glucose oxidase (EC 1.1.3.4), and peroxidase (EC 1.11.1.7) from different sources (Sigma-Aldrich Inc., St. Louis, $\mathrm{MO})$. The experiment was conducted in 3 steps.

\subsubsection{Step 1: determination of optimal $\alpha$-amylase (ANKOM Technology Inc., Macedon, NY) concentration}

Alpha-amylase from ANKOM Technology Inc. (Macedon, NY) was introduced as a new enzyme source to replace $\alpha$ amylase from Megazyme International Ireland Ltd. (Wicklow, Ireland). The optimal $\alpha$-amylase concentration for the assay was tested at increasing $\alpha$-amylase concentrations of 465, 697, 930, 1162, 1394, and 1627liquefon units (LU)/assay to measure total starch concentration of pure corn starch. The range of $\alpha$-amylase concentrations (465-1627 LU/assay) for step 1 was based on the total number of $\alpha$-amylase units/assay use in the AOAC method 996.11 (AOAC, 2005; 300 U/assay) and acetate buffer method ( 1500 LU/assay; Hall, 2009). The starch analysis in step 1 was completed according to AOAC method 996.11 (AOAC, 2005). Reagents and enzymes from a Total Starch Assay Kit (Megazyme International Ireland Ltd., Wicklow, Ireland) were used except for $\alpha$-amylase which was purchased from ANKOM Technology Inc. (Macedon, NY). The optimal $\alpha$-amylase concentration was determined based on the percentage of starch recovery of the pure corn starch (100\%). 


\subsubsection{Step 2: determination of optimal amyloglucosidase (Sigma-Aldrich Inc., St. Louis, MO) concentration}

Amyloglucosidase from Sigma-Aldrich Inc. (St. Louis, MO) was introduced as a new enzyme source to replace amyloglucosidase from Megazyme International Ireland Ltd. (Wicklow, Ireland). The optimal amyloglucosidase concentration for the assay was tested at increasing amyloglucosidase concentrations of 300, 400, 500 and 600 units per assay to measure total starch concentration of pure corn starch. The range of amyloglucosidase concentrations (300-600 LU/assay) for step 2 was based on the total number of amyloglucosidase units/assay use in the AOAC method 996.11 (AOAC, 2005; $330 \mathrm{U} /$ assay) and acetate buffer method (200 LU/assay; Hall, 2009). The starch analysis in step 2 was completed according to AOAC method 996.11 (AOAC, 2005). Reagents and enzymes from a Total Starch Assay Kit (Megazyme International Ireland Ltd., Wicklow, Ireland) were used except for amyloglucosidase which was purchased from Sigma-Aldrich Inc. (St. Louis, MO). The optimal amyloglucosidase concentration per assay was determined based on the percentage of starch recovery of the pure corn $\operatorname{starch}(100 \%)$.

\subsubsection{Step 3: comparison of $A O A C$ method with Modified $A O A C$ (MAOAC) method}

Two methods, AOAC and MAOAC method were compared by analyzing nine different samples. All samples were analyzed in duplicate within each run. Two technicians were used and each technician performed two runs of each method. The AOAC method was performed in open-test tubes whereas the MAOAC method was performed in sealable test tubes as described by Hall (2009). Sample blanks were done for both methods to measure free glucose of the samples and correct for free glucose.

\subsection{Apparatus-AOAC and MAOAC methods}

a) Grinding mill. Centrifugal, with 12 -tooth rotor and $0.5 \mathrm{~mm}$ sieve, or similar device. Alternatively, a cyclone mill can be used for small quantities.

b) Bench centrifuge. Capable of holding $16 \mathrm{~mm} \times 125 \mathrm{~mm}$ glass test tubes, with a rating of $1000 \times \mathrm{g}$.

c) Water bath. Capable of maintaining $50 \pm 1{ }^{\circ} \mathrm{C}$.

d) Boiling water bath.

e) Vortex mixer.

f) $\mathrm{pH}$ meter.

g) Stop-clock timer (digital).

h) Top-loading balance.

i) Analytical balance. Capable of weighing accurately to $\pm 0.0001 \mathrm{~g}$.

j) Laboratory oven. With forced-convection; maintaining $103 \pm 1{ }^{\circ} \mathrm{C}$; used for determining dry weight of test samples.

k) Spectrophotometer with a microplate reader. Capable of measuring absorbance at $510 \mathrm{~nm}$.

1) Pipets. Capable of delivering 0.1, 0.2, and $1.0 \mathrm{~mL}$; with disposable tips.

$\mathrm{m})$ Positive-displacement repeating pipet. Capable of accurately delivering $0.1,0.2,0.4,2.0,3.0,4.0$, and $9.0 \mathrm{~mL}$.

n) Glass test tubes. $16 \mathrm{~mm} \times 120 \mathrm{~mm}, 16 \mathrm{~mm} \times 125 \mathrm{~mm}$ with polytetrafluoroethylene (PTFE)-lined screw caps and $18 \mathrm{~mm} \times 150 \mathrm{~mm}$.

o) Test tube racks. 48 capacity, holding $16 \mathrm{~mm} \times 120 \mathrm{~mm}, 16 \mathrm{~mm} \times 125 \mathrm{~mm}$ and $18 \mathrm{~mm} \times 150 \mathrm{~mm}$.

p) Thermometer. Reading at $103 \pm 1 \circ \mathrm{C}$.

\subsection{Reagents and solutions}

\subsubsection{AOAC method}

(a) 3-(N-Morpholino)propanesulfonic acid (MOPS) buffer (pH 7.0). MOPS buffer contained $50 \mathrm{mmol} / \mathrm{L}$ MOPS, and $5 \mathrm{mmol} / \mathrm{L}$ calcium chloride, and $0.2 \mathrm{~g} / \mathrm{L}$ sodium azide. In $1 \mathrm{~L}$ volumetric flask, $11.55 \mathrm{~g}$ of MOPS was dissolved in $900 \mathrm{~mL}$ distilled water, and $\mathrm{pH}$ was adjusted to 7.0 with $1 \mathrm{~mol} / \mathrm{L} \mathrm{HCl}$ (ca $17 \mathrm{~mL}$ ). $0.74 \mathrm{~g}$ of $\mathrm{CaCl}_{2} \cdot 2 \mathrm{H}_{2} \mathrm{O}$ and $0.2 \mathrm{~g}$ of sodium azide were added. The buffer was diluted to $1 \mathrm{~L}$ with distilled water.

(b) Thermostable $\alpha$-amylase solution. $10 \mathrm{~mL} ; 3000 \mathrm{U} / \mathrm{mL}$. $1 \mathrm{~mL}$ of $\alpha$-amylase solution (in $500 \mathrm{~mL} / \mathrm{L}$ glycerol) was diluted to $30 \mathrm{~mL}$ with MOPS buffer, (a) Alpha-amylase reagent was supplied in the Total Starch Assay Kit [AOAC Method 996.11 (AOAC, 2005); Megazyme International Ireland, Ltd; origin: B. licheniformis; optimum pH, 6.0-6.5].

(c) Amyloglucosidase solution. $10 \mathrm{~mL} ; 200 \mathrm{U} / \mathrm{mL}$. Used directly without dilution. This reagent was supplied in the Total Starch Assay Kit [AOAC Method 996.11 (AOAC, 2005), Megazyme International Ireland, Ltd; origin: Aspergillus niger; optimum $\mathrm{pH}, 4.0$; stable $\mathrm{pH}, 4.0-5.5]$.

(d) Glucose oxidase-peroxidase-aminoantipyrine buffer mixture (GOPOD). Mixture of glucose oxidase, 12,000 U/L; peroxidase, $650 \mathrm{U} / \mathrm{L}$; and 4-aminoantipyrine, $0.4 \mathrm{mmol} / \mathrm{L}$ in a buffer containing $\mathrm{KH}_{2} \mathrm{PO}_{4}, \mathrm{NaOH}$, 4-hydroxybenzoic acid, and sodium azide. This reagent was supplied in the Megazyme Total Starch Assay Kit [AOAC Method 996.11 (AOAC, 2005), Megazyme International Ireland, Ltd].

(e) Aqueous ethanol. About $800 \mathrm{~mL} / \mathrm{L} .84 \mathrm{~mL}$ of $95 \mathrm{~mL} / \mathrm{L}$ ethanol was diluted (laboratory grade) to $100 \mathrm{~mL}$ with distilled water.

(f) Sodium acetate buffer, $200 \mathrm{mmol} / \mathrm{L}, p H 4.5 .11 .8 \mathrm{~mL}$ of glacial acetic acid (ACS grade, $1050 \mathrm{~kg} / \mathrm{m}^{3}$ ) was pipetted into $900 \mathrm{~mL}$ distilled water. The $\mathrm{pH}$ was adjusted to 4.5 with $1 \mathrm{mmol} / \mathrm{L} \mathrm{NaOH}$ solution and $0.2 \mathrm{~g}$ sodium azide later. The buffer was diluted to $1 \mathrm{~L}$ with distilled water. 
(g) Dimethyl sulfoxide (DMSO). Laboratory grade.

(h) Glucose standard stock solution. $1 \mathrm{~g} / \mathrm{L}$. This reagent was used as supplied in the Total Starch Assay Kit [AOAC Method 996.11 (AOAC, 2005); Megazyme International Ireland, Ltd].

\subsubsection{MAOAC method}

(i) 3-(N-Morpholino)propanesulfonic acid (MOPS) buffer (pH 7.0). Prepared according to AOAC Method 996.11 (AOAC, 2005) (a).

(j) Thermostable $\alpha$-amylase solution. $388 \mathrm{LU} / \mathrm{mL}$; Alpha-amylase $(2.5 \mathrm{~mL})$ from B. licheniformis was pipetted $(18,592 \mathrm{LU} / \mathrm{g}$; specific gravity=1.20; optimum pH, 5.5-7.0; ANKOM Technology Inc., Macedon, NY) into a $100 \mathrm{~mL}$ volumetric flask and diluted to $100 \mathrm{~mL}$ with MOPS buffer, $\mathrm{pH} 7.0$ (i).

(k) Sodium acetate buffer, $200 \mathrm{mmol} / \mathrm{L}, \mathrm{pH}$ 4.5. Prepared according to AOAC Method 996.11 (AOAC, 2005) (f).

(1) Amyloglucosidase solution. $1000 \mathrm{U} / \mathrm{mL} ; 138 \mathrm{mg}$ of amyloglucosidase from A. niger (73 U/mg; Sigma-Aldrich Inc., St. Louis, MO) was dissolved in $10 \mathrm{~mL}$ sodium acetate buffer, $200 \mathrm{mmol} / \mathrm{L}, \mathrm{pH} 4.5(\mathrm{k})$.

(m) Aqueous ethanol. Prepared according to AOAC Method 996.11 (AOAC, 2005) (e).

(n) Dimethyl sulfoxide (DMSO). Laboratory grade.

(o) Glucose oxidase-peroxidase-aminoantipyrine buffer mixture (GOPOD). Prepared according to acetate buffer method (Hall, 2009). Mixture was $7000 \mathrm{U} / \mathrm{L}$ of glucose oxidase (Sigma-Aldrich Inc., St. Louis, MO), 7000 U/L of peroxidase (Sigma-Aldrich Inc., St. Louis, MO), and $0.74 \mathrm{mmol} / \mathrm{L}$ of 4 -aminoantipyrine. The mixture was prepared by dissolving $9.1 \mathrm{~g}$ of $\mathrm{Na}_{2} \mathrm{HPO}_{4}$ and $5.0 \mathrm{~g}$ of $\mathrm{KH}_{2} \mathrm{PO}_{4}$ in approximately $800 \mathrm{~mL}$ of distilled water in a $1 \mathrm{~L}$ glass beaker using a magnetic stirrer. Immediately following, $1.0 \mathrm{~g}$ of phenol (ACS grade) and $0.15 \mathrm{~g}$ of 4 -aminoantipyrine were added. Glucose oxidase $(7000 \mathrm{U})$ and peroxidase $(7000 \mathrm{U})$ were then added and the contents were gently stirred to dissolve the enzymes without causing excessive foaming. The contents were transferred to a $1 \mathrm{~L}$ volumetric flask and diluted to $1 \mathrm{~L}$ with distilled water. The flask was sealed and inverted repeatedly to mix. The reagent was stored in a sealed amber bottle at $4 \circ \mathrm{C}$.

(p) Glucose standard solutions. Prepared according to acetate buffer method (Hall, 2009). 0 and $1000 \mu \mathrm{g} / \mathrm{mL}$. Benzoic acid solution of $2 \mathrm{~g} / \mathrm{L}$ was prepared and used as $0 \mu \mathrm{g} / \mathrm{mL}$ glucose standard. The DM of powdered crystalline glucose (purity $\geq 995 \mathrm{~g} / \mathrm{kg}$ ) was determined. Approximately $50 \mathrm{mg}$ of glucose was weighed to the nearest $0.0001 \mathrm{~g}$. Weighed glucose was dissolved in $2 \mathrm{~g} / \mathrm{L}$ benzoic acid solution and diluted to $500 \mathrm{~mL}$. The concentration of glucose solution was calculated by multiplying the weight of glucose by the concentration of DM, and dividing by $500 \mathrm{~mL}$.

\subsection{Procedures}

\subsubsection{AOAC method}

The AOAC method was performed according to the instructions provided with the Total Starch Assay Kit [AOAC Method 996.11 (AOAC, 2005); Megazyme International Ireland, Ltd].

(1) D-Glucose, corn starch, and reagent blanks were included with each set of test samples.

(2) The accurately weighed milled sample $(\sim 100 \mathrm{mg})$ was added to a glass tube $(16 \mathrm{~mm} \times 120 \mathrm{~mm})$ and the tube was gently tapped on the laboratory bench to ensure that all particles dropped to bottom of the tube.

(3) Aqueous ethanol [0.2 mL; $800 \mathrm{~mL} / \mathrm{L}$; (e)] was added to aid dispersion, and the tube was stirred on a vortex mixer.

(4) Immediately following, $2 \mathrm{~mL}$ of DMSO; ( $\mathrm{g}$ ) was added and the tube was stirred on a vortex mixer. The tube was placed in a vigorously boiling water bath and removed after $5 \mathrm{~min}$.

Note: DMSO was not added to ground corn and pure starch samples.

(5) Following removal from the water bath, $3 \mathrm{~mL}$ of thermostable $\alpha$-amylase (b) was added. The tube was again incubated in a boiling water bath for $6 \mathrm{~min}$. (The tube was stirred vigorously after 2, 4 and $6 \mathrm{~min}$.)

(6) After incubation, the tube was placed in a water bath at $50{ }^{\circ} \mathrm{C} .4 .0 \mathrm{~mL}$ of $\mathrm{Na}$ acetate buffer (f) and $0.1 \mathrm{~mL}$ of amyloglucosidase (c) were added. The tube was stirred on a vortex mixer and incubated at $50{ }^{\circ} \mathrm{C}$ for $30 \mathrm{~min}$.

(7) The contents of the test tube (samples with $>100 \mathrm{~g} / \mathrm{kg}$ starch) were transferred to a $100 \mathrm{~mL}$ volumetric flask (with a funnel to assist transfer). A wash bottle was used to rinse the tube contents. The volume was adjusted to $100 \mathrm{~mL}$ with distilled water and mixed. The volume of the test tube was adjusted to $10 \mathrm{~mL}$ when sample starch concentration was $<100 \mathrm{~g} / \mathrm{kg}$. An aliquot of this solution was centrifuged at $1000 \times \mathrm{g}$ for $10 \mathrm{~min}$. The clear, undiluted filtrate was used for the assay.

(8) Duplicate aliquots $(0.1 \mathrm{~mL})$ of the diluted solution were transferred to the bottom of glass test tubes $(16 \mathrm{~mm} \times 100 \mathrm{~mm})$.

(9) GOPOD reagent $(\mathrm{d})(3.0 \mathrm{~mL})$ was added to each tube (including the D-glucose controls and reagent blanks). The tubes were stirred on a vortex mixer and incubated at $50^{\circ} \mathrm{C}$ for $20 \mathrm{~min}$.

(10) D-Glucose controls were consisted of $0.1 \mathrm{~mL}$ of D-glucose standard solution $(1 \mathrm{~g} / \mathrm{L})$ and $3.0 \mathrm{~mL}$ of GOPOD reagent. Reagent Blank solutions consisted of $0.1 \mathrm{~mL}$ of water and $3.0 \mathrm{~mL}$ of GOPOD reagent.

(11) The absorbance for each sample and the D-glucose control was read at $510 \mathrm{~nm}$ against the reagent blank. 


\subsubsection{MAOAC method}

(1) D-glucose, corn starch, and reagent blanks were included with each set of test samples.

(2) The accurately weighed milled sample was added $(75-85 \mathrm{mg})$ to a glass centrifuge tube $(16 \mathrm{~mm} \times 125 \mathrm{~mm})$ with PTFElined screw caps.

(3) Aqueous ethanol $[0.2 \mathrm{~mL}, 800 \mathrm{~mL} / \mathrm{L}(\mathrm{m})]$ was added to aid dispersion, and tube was capped and stirred on a vortex mixer.

(4) Immediately, $2 \mathrm{~mL}$ of DMSO ( $\mathrm{n}$ ) was added. The tube was capped and stirred on a vortex mixer. The tube was placed in a vigorously boiling water bath and removed after $5 \mathrm{~min}$.

Note: DMSO was not added to ground corn and pure starch samples.

(5) Alpha-amylase in MOPS buffer of $3.0 \mathrm{~mL}$ [pH 7.0; (j)] was added. The tube was capped and stirred on a vortex mixer. The tube was incubated in a boiling water bath for $15 \mathrm{~min}$. (The tube was stirred vigorously after 5 and $10 \mathrm{~min}$.)

(6) Sodium acetate buffer of $4.0 \mathrm{~mL}[\mathrm{pH} 4.5$, (k)] was added. The tube was capped and stirred on a vortex mixer.

(7) Amyloglucosidase solution in Na acetate buffer of $0.4 \mathrm{~mL}$ [400 U/assay (1)] was added. The tube was capped and stirred on a vortex mixer.

(8) The tube was incubated at $50^{\circ} \mathrm{C}$ for $30 \mathrm{~min}$.

(9) Distilled water of $0.4 \mathrm{~mL}$ (samples with DMSO) or $2.4 \mathrm{~mL}$ (samples without DMSO) was added to bring the total solution volume up to $10 \mathrm{~mL}$. The tube was capped and stirred on a vortex mixer.

Note: $10 \mathrm{~mL}-(0.2 \mathrm{~mL}$ of ethanol $+2 \mathrm{~mL}$ of DMSO $+3 \mathrm{~mL}$ of amylase $+4 \mathrm{~mL}$ of $\mathrm{Na}$ acetate $+0.4 \mathrm{~mL}$ of amyloglucosidase $)=0.4 \mathrm{~mL}$.

Note: $10 \mathrm{~mL}-(0.2 \mathrm{~mL}$ of ethanol $+3 \mathrm{~mL}$ of amylase $+4 \mathrm{~mL}$ of Na acetate $+0.4 \mathrm{~mL}$ of amyloglucosidase $)=2.4 \mathrm{~mL}$.

Note: Distilled water of $2.4 \mathrm{~mL}$ was added to ground corn and pure starch samples.

(10) The tube was centrifuged at $1000 \times g$ for $10 \mathrm{~min}$.

(11) (a) For samples containing $>100 \mathrm{~g} / \mathrm{kg}$ starch; $1 \mathrm{~mL}$ of solution was pipetted into a $16 \mathrm{~mm} \times 100 \mathrm{~mm}$ test tube and $9 \mathrm{~mL}$ of distilled water was added to bring the total volume up to $10 \mathrm{~mL}$. The tube was capped and stirred on a vortex mixer. (b) For samples containing $<100 \mathrm{~g} / \mathrm{kg}$ starch, the solution was not diluted and used as it was for glucose analysis.

(12) Duplicate aliquots $(0.1 \mathrm{~mL})$ from the solutions of step 11(a) or 11(b) were transferred to the bottom of glass test tubes $(16 \mathrm{~mm} \times 100 \mathrm{~mm})$.

(13) GOPOD reagent of $3.0 \mathrm{~mL}$ was added to each tube (including the D-glucose controls and reagent blanks). The tubes were stirred on a vortex mixer and incubated at $50^{\circ} \mathrm{C}$ for $20 \mathrm{~min}$.

(14) D-Glucose controls were consisted of $0.1 \mathrm{~mL}$ of D-glucose standard solution $(1 \mathrm{~g} / \mathrm{L})$ and $3.0 \mathrm{~mL}$ of GOPOD reagent. Reagent Blank solutions consisted of $0.1 \mathrm{~mL}$ of water and $3.0 \mathrm{~mL}$ of GOPOD reagent.

(15) The content of $1.0 \mathrm{~mL}$ from incubated solution was transferred to a 48 -well microplate using a $1 \mathrm{~mL}$ pipette.

(16) The absorbance was read at $510 \mathrm{~nm}$ using a microplate reader.

\subsection{Calculations}

Total starch concentrations ( $\mathrm{g} / \mathrm{kg}$, on as is basis) were calculated as follows:

$$
\text { Total } \operatorname{starch}(\mathrm{g} / \mathrm{kg})=A \times F \times V \times \frac{1}{1000} \times \frac{1}{W} \times \frac{162}{180} \times 1000
$$

where $A=$ absorbance of reaction solutions read vs. reagent blank; $F=$ factor to convert absorbance values to $\mu \mathrm{g}$ glucose $=100 \mu \mathrm{g}$ glucose/absorbance value for $100 \mu \mathrm{g}$ glucose; $V=$ volume correction, if $0.1 \mathrm{~mL}$ taken from $100 \mathrm{~mL}$ (for AOAC method) or $0.1 \mathrm{~mL}$ taken from the dilution technique (for MAOAC method), $V=1000$ (for samples contain $>100 \mathrm{~g} / \mathrm{kg}$ starch); if $0.1 \mathrm{~mL}$ taken from $10 \mathrm{~mL}, V=100$ (for samples contain $<100 \mathrm{~g} / \mathrm{kg}$ starch); $1 / 1000=$ conversion from $\mu \mathrm{g}$ to $\mathrm{mg}$; $W=$ weight of the sample; $162 / 180=$ factor to convert from free glucose, as determined, to anhydroglucose, as present in starch; $1000=$ factor to convert total starch as $\mathrm{g} / \mathrm{kg}$.

Limits of detection (AOAC, 2002) were calculated for AOAC and MAOAC methods using mean blank value $+3 \times$ blank standard deviations. The average of 4 replicates $\times 2$ runs $\times 2$ technicians was used when calculating the mean value of absorbance \pm standard deviations of the undiluted reagent blanks for each method. Starch detection limits were calculated by applying the absorbance values for limits of detection to the equation used to calculate the starch concentration. Sample weight of $100 \mathrm{mg}$ with $900 \mathrm{~g} / \mathrm{kg}$ DM was used for these calculations.

\subsection{Statistical and cost analysis}

Data were analyzed in a completely randomized design using the MIXED procedure of SAS v. 9.02 (SAS Institute Inc., Cary, NC). The effects of sample, method, technician, run and their interactions were included in the model. Non-significant interactions were deleted during the data analysis, but sample $\times$ method was left in the model. Mean separation was done using Tukey's test at $P<0.05$.

A cost analysis was conducted to compare the cost of the chemicals used in the AOAC method and the MAOAC method. Retail prices for United States as of September 2016 were used for the calculations from Megazyme International Ireland Ltd. 
Table 1

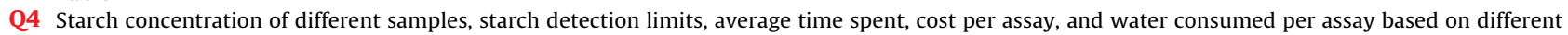
assay procedures.

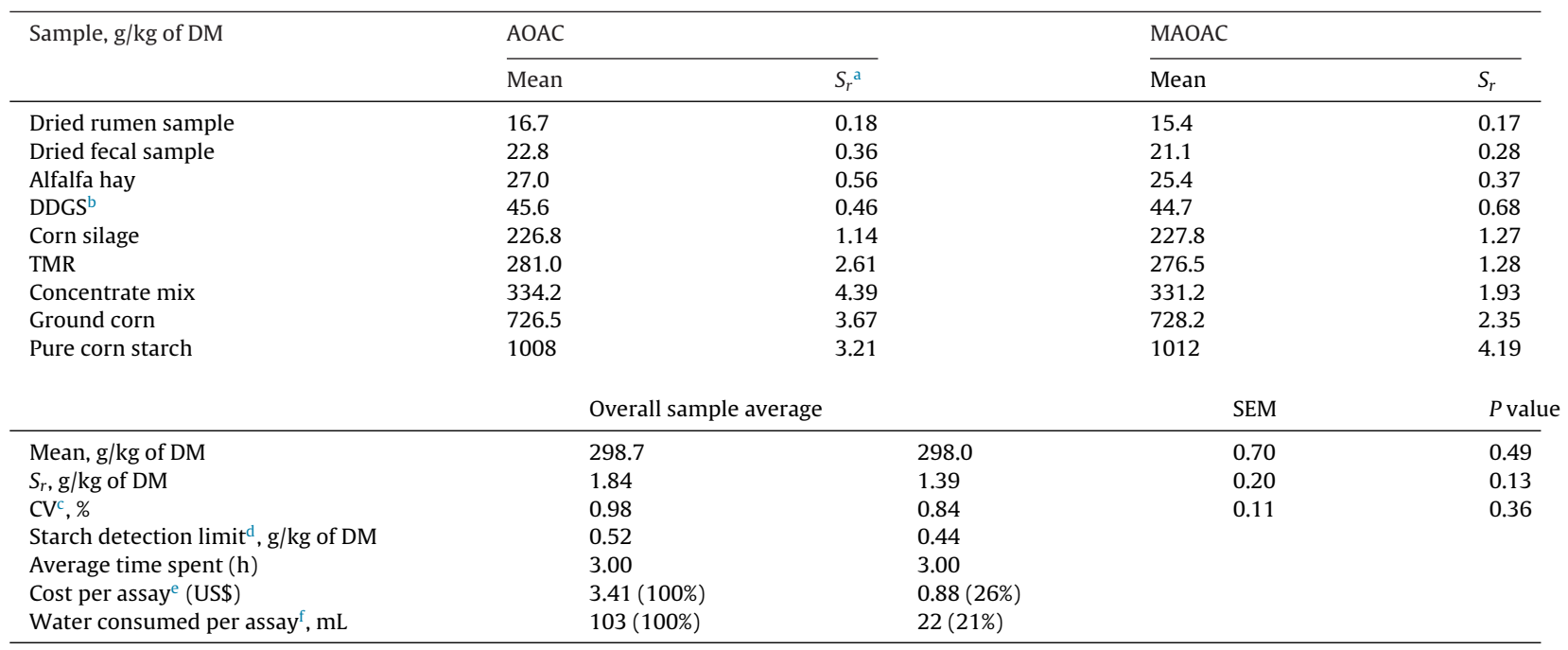

a $S_{r}=$ standard deviation of replicates.

b $\mathrm{DDGS}=$ dried distillers grains with solubles.

c $\mathrm{CV}, \%=$ coefficient of variation $\left(S_{r} /\right.$ mean $\left.\times 100\right)$.

d Starch detection limit was calculated using the detection limit absorbance values of undiluted reagent blanks $($ detection limit absorbance value $=$ mean blank value $+3 \times$ blank standard deviations; AOAC, 2002) and by applying the detection limit absorbance values to the equation used to calculate the starch concentration. Sample weight of $100 \mathrm{mg}$ with $900 \mathrm{~g} / \mathrm{kg}$ DM was considered for the calculations.

e The cost analysis included only the cost of chemicals used in the analysis.

${ }^{\mathrm{f}}$ For samples $>100 \mathrm{~g} / \mathrm{kg}$ starch, DM.

(Wicklow, Ireland), Sigma-Aldrich Inc. (St. Louis, MO) and ANKOM Technology Inc. (Macedon, NY). The cost for the distilled water was not included in the calculations.

\section{Results}

The determined optimal $\alpha$-amylase and amyloglucosidase concentrations for the MAOAC method were 1162 liquefon units and 400 units per assay, respectively. Table 1 shows starch concentration and standard deviation of each sample, starch concentration and standard deviations of all samples, coefficient of variations (CV) for the all samples, starch detection limits, average time spent on each method, cost per assay, and water consumption per assay for the AOAC and MAOAC methods.

The average starch concentrations for the AOAC and the MAOAC methods were 298.7 and $298.0 \mathrm{~g} / \mathrm{kg}$ (DM basis) respectively and were not statistically different $(P=0.49)$.

The average starch concentration was not affected by the technician $(P=0.24 ; \mathrm{AOAC}=297.8 ; \mathrm{MAOAC}=299.0 \mathrm{~g} / \mathrm{kg} ; P=0.13)$ and run $(P=0.59$; run $1=298.7$; run $2=298.1 \mathrm{~g} / \mathrm{kg} ; P=0.56)$. There was no effect of method $\times$ samples interaction $(P=0.63)$. Average starch concentrations ranged from 16.1 to $1010.1 \mathrm{~g} / \mathrm{kg}$ across all the various samples for both AOAC and MAOAC methods.

The average standard deviations of the replicates for starch analysis was not affected by the method (AOAC $=18.4$; $\mathrm{MAOAC}=13.9 \mathrm{~g} / \mathrm{kg} ; P=0.13$ ) and run (run $1=15.3$; run $2=17.0 \mathrm{~g} / \mathrm{kg} ; P=0.56$ ). Technician 2 had lower standard deviation compared to technician $1(1.28 \mathrm{vs} .1 .96 \mathrm{~g} / \mathrm{kg} ; P=0.02)$. The average $\mathrm{CV}$ for both methods and two runs were 0.91 and $0.91 \%$ and there were no effects of method $(P=0.36)$ or run $(P=0.36)$ (data not shown). There was an effect of technician $(P=0.001)$ on $\mathrm{CV}$ as technician 2 had lower $\mathrm{CV}$ compared to technician 1 (0.67 vs. 1.15\%).

The mean absorbance \pm standard deviation of undiluted blanks for the AOAC and MAOAC methods were $0.026 \pm 0.002$ and $0.025 \pm 0.002$, respectively. The calculated limits of detection were 0.033 and 0.031 of absorbance for the AOAC and the MAOAC methods, respectively. The calculated starch detection limits were 0.52 for the AOAC method and $0.44 \mathrm{~g} / \mathrm{kg}$ for the MAOAC method, respectively based on DM basis.

The average time spent on both methods was approximately $3 \mathrm{~h}$ for 18 assays. Average cost of the assay with the MAOAC method was $\$ 0.84$ /assay compared with $\$ 3.40$ /assay for the AOAC method. The calculated amount of water consumed for the samples containing $>100 \%$ starch were $22 \mathrm{~mL}$ and $103 \mathrm{~mL}$ for the MAOAC method and AOAC method, respectively. 


\section{Discussion}

\subsection{Selection of samples}

Nine samples were selected to represent varying starch concentrations and compositions, i.e. samples with and without resistant starch. Rumen contents, fecal samples, alfalfa hay, and dried distillers grains with solubles were selected as representatives of low starch samples. Corn silage, lactating dairy cow TMR, and concentrate mix were selected as medium starch samples. Dry ground corn and pure corn starch was selected as high starch samples. Dry ground corn and pure corn starch samples were considered as samples without resistant starch and the remainder were considered as samples with resistant starch. All samples analyzed in this study were representative of samples analyzed by commercial analytical laboratories.

\subsection{Comparison of the methods}

Despite an effect of technician for the standard deviation, the standard deviations observed in our study were comparable or less than the repeatability standard deviation values previously reported for starch assays by McCleary et al. (1997; $15-35 \mathrm{~g} / \mathrm{kg}$ ) or Hall $(2009 ; 2.0-8.8 \mathrm{~g} / \mathrm{kg})$. Also, CV values reported in our study were comparable or less than previously reported CV values for starch assays (Hall, 2009; 0.26-2.57). Hall (2009) reported a detection limit of 0.033 absorbance for the extension of the AOAC method. This was comparable with detection limits ( 0.033 and 0.031$)$ determined in our study.

In the AOAC method, volumizing samples with $>100 \mathrm{~g} / \mathrm{kg}$ starch after the enzymatic incubation was tedious, time consuming, and needed to be done with precision. In the MAOAC method, using sealable test tubes was more time consuming (capping and uncapping during the assay) than sample preparation for the AOAC method. Additionally, time spent on incubation with $\alpha$-amylase was greater ( $15 \mathrm{~min}$ compared to $6 \mathrm{~min}$ ) for the MAOAC method compared with AOAC method. However, the technique of dilution by pipetting consumed less time compared with dilution by volumetric flask. In summary, the additional time spent for the MAOAC method during the early steps was offset by less time required during the pipetting step and as a result there were no differences in time required between the MAOAC and AOAC methods.

\subsection{Modification of the AOAC method}

Eight modifications were implemented with the MAOAC method. Each modification is discussed separately.

\subsubsection{Introduction of alternative sources for enzymes used in the assay}

Enzymes, $\alpha$-amylase, amyloglucosidase, glucose oxidase, and peroxidase introduced in the MAOAC method were purchased from alternative sources. Alpha-amylase purchased from ANKOM Technology Inc., Macedon, NY (from B. licheniformis; pH optima 5.5-7.0; ca 18,592 LU/g; specific gravity =1.20) was similar to $\alpha$-amylase (from B. licheniformis; pH optima 5.5-5.8; ca $20,000 \mathrm{LU} / \mathrm{g}$; specific gravity $=1.25$ ) used in the acetate buffer method (Hall, 2009). There are reports on possible contaminations of commercially available $\alpha$-amylase and amyloglucosidase with other enzymes such as cellulases (Rose et al., 1991), hemicellulases (Rose et al., 1991) and transglucosidase (McCleary and Gibson, 1989). These contaminations could lead to an overestimate (Omi and Rose, 1991; McCleary et al., 1994) or underestimate (McCleary and Gibson, 1989) of the starch concentration of the samples. Omi and Rose (1991) reported that there were no differences between concentrations of starch when samples were analyzed using commercially available enzymes compared to purified enzymes. Those authors suggested that the purity of the commercial enzymes from reliable sources would be sufficient for use in the starch determination.

The method described in the acetate buffer method (Hall, 2009) was used to prepare GOPOD reagent. Therefore, glucose oxidase and peroxidase enzymes were purchased from Sigma-Aldrich Inc. (St. Louis, MO) as described in the acetate buffer method (Hall, 2009).

\subsubsection{Declaration of the optimal enzyme concentrations per assay}

It was possible to declare optimal $\alpha$-amylase $(1162 \mathrm{LU})$ and amyloglucosidase $(400 \mathrm{U})$ concentrations per assay for the MAOAC method. As we adapted the method to prepare GOPOD reagent from acetate buffer method, the optimal enzyme concentrations described in the acetate buffer method (Hall, 2009) were used for glucose oxidase and peroxidase enzymes in MAOAC method.

\subsubsection{Use of sealable test tubes for the enzymatic digestion}

Sealable test tubes were used to incubate the samples with $\alpha$-amylase and amyloglucosidase in the acetate buffer method (Hall, 2009) and this modification was incorporated into the MAOAC method. The advantage of using the sealable tests tubes was that it prevented evaporation losses of the volume during the incubation with DMSO, $\alpha$-amylase and amyloglucosidase. Therefore, the exact volume in the vessel was known after the incubation with DMSO, $\alpha$-amylase, and amyloglucosidase and it was easy to adjust the sample solution volume to $10 \mathrm{~mL}$. 


\subsubsection{Clear instructions to dilute the samples with $<100 \mathrm{~g} / \mathrm{kg}$ starch after the incubation with enzymes}

One of the drawbacks of the AOAC method was that no clear instructions were given on adjusting the volume to $10 \mathrm{~mL}$ for samples with $<100 \mathrm{~g} / \mathrm{kg}$ starch after the enzymatic digestion. It was not possible to transfer the entire contents of the test tube to a $10 \mathrm{~mL}$ volumetric flask and it was difficult to adjust the volume to $10 \mathrm{~mL}$ in the same test tube in which the sample was incubated with the enzymes. The difficulty arose in estimating the volume lost during the incubation with DMSO and enzymes. Graduated $10 \mathrm{~mL}$ test tubes were used to overcome this problem when the AOAC method was performed. However, this step was inconvenient and could be considered as one of the steps in the AOAC method that could lead to increase the variability among the replicates. In the MAOAC method, the samples treated with DMSO had total volume of $9.6 \mathrm{~mL}$ and the samples that were not treated with DMSO had total volume of $7.6 \mathrm{~mL}$ after the enzymatic incubation. Therefore, $0.4 \mathrm{~mL}$ and $2.4 \mathrm{~mL}$ of distilled water were added to the samples treated with and without DMSO, respectively, to adjust the volume to $10 \mathrm{~mL}$.

\subsubsection{Introduction of a technique, dilution by pipetting for the samples with $>100 \mathrm{~g} / \mathrm{kg}$ starch}

Dilution of samples with $>100 \mathrm{~g} / \mathrm{kg}$ starch to $100 \mathrm{~mL}$ after the enzymatic digestion using a volumetric flask was recognized as another inconvenient step in the AOAC method. Transferring the whole contents of the test tube to a volumetric flask and volumizing up to $100 \mathrm{~mL}$ needs to be done with utmost care, as this step may lead to increase variability among the replicates. Therefore, in the MAOAC method, samples containing $>100 \mathrm{~g} / \mathrm{kg}$ starch were adjusted to $10 \mathrm{~mL}$ by adding 0.4 or $2.4 \mathrm{~mL}$ of distilled water (depending on the addition of $2 \mathrm{~mL}$ of DMSO or not) and diluted by pipetting ( $1 \mathrm{~mL}$ sample and $9 \mathrm{~mL}$ of distilled water) rather than using a $100 \mathrm{~mL}$ volumetric flask. This step was adopted from acetate buffer method (Hall, 2009).

\subsubsection{Introduction of GOPOD reagent from acetate buffer method}

The GOPOD reagent used in the MAOAC was prepared according to acetate buffer method (Hall, 2009). It was chosen based on the ease of preparation as fewer chemicals were used compared to the AOAC method and there was no step involved to adjust the $\mathrm{pH}$ of the reagent.

\subsubsection{Reduction of the cost per assay}

It was possible to reduce the cost of chemicals per assay of MAOAC method by $74 \%$ compared to the AOAC method. The reduced assay cost for the MAOAC method was attributable to introducing enzymes, $\alpha$-amylase and amyloglucosidase, glucose oxidase and peroxidase from alternative sources.

It is possible to pipette $33 \mu \mathrm{L}$ of the final sample solution and $1 \mathrm{~mL}$ of GOPOD reagent into a 48 -well microplate instead of pipetting $100 \mu \mathrm{L}$ of the final sample solution and $3 \mathrm{~mL}$ of GOPOD reagent into a test tube. However, this step was not a part of the methodology of the modified AOAC method. It is a suggestion based on the authors' experience to further reduce the time and cost of the analysis.

\subsubsection{Reduction of the water consumption for the samples containing $>100 \mathrm{~g} / \mathrm{kg}$ starch}

It was possible to reduce the water consumption by $79 \%$ for the samples containing $>100 \mathrm{~g} / \mathrm{kg}$ starch compared to the AOAC method as we adapted the technique, dilution by pipetting from acetate buffer method (Hall, 2009). This reduction could help to further decrease the cost per assay when the distilled water is expensive, as the cost for distilled water was not included in the cost analysis.

\subsection{Additional comments on the modified method}

The advantages of using DMSO to gelatinize the starch were that it was a simple method (add $2 \mathrm{~mL}$ and incubate at $100^{\circ} \mathrm{C}$ for $5 \mathrm{~min}$ ) and the ability to use the same boiling water bath for the following enzyme incubation. However, the use of DMSO as a laboratory chemical could be debatable. It is suggested that DMSO is a solvent of a low toxicity and it could be used in medical treatments for humans (Kelava et al., 2011). On the other hand, there is evidence to suggest that DMSO may not be safe for humans (Takeda et al., 2016; Windrum and Morris, 2003). Therefore, use of KOH method (McCleary et al., 2002) to gelatinize the could be considered as a laboratory safe method despite the $\mathrm{KOH}$ method would require an additional ice water bath and longer time for the incubation $(20 \mathrm{~min})$ with stirring.

\section{Conclusions}

The MAOAC method yielded similar recoveries of starch from samples containing different starch compositions and concentrations compared to the AOAC method. Eight modifications were implemented with the MAOAC method. Modifications were: (1) $\alpha$-amylase, amyloglucosidase, glucose oxidase, and peroxidase were introduced from alternative sources, (2) the optimal concentrations for $\alpha$-amylase and amyloglucosidase per assay were declared, (3) sealable test tubes were used for the enzymatic digestion instead of using open test tubes, (4) clear instructions were provided to dilute the samples with $<100 \mathrm{~g} / \mathrm{kg}$ starch after the incubation with enzymes, (5) a technique of dilution by pipetting was introduced from acetate buffer method (Hall, 2009) for the samples with $>100 \mathrm{~g} / \mathrm{kg}$ starch, (6) GOPOD reagent from acetate buffer method (Hall, 2009 ) introduced, (7) the chemical cost per assay was decreased by $74 \%$ compared to the AOAC method, and (8) the water 
consumption was decreased by $79 \%$ for the samples containing $>100 \mathrm{~g} / \mathrm{kg}$ starch compared to the AOAC method. Therefore, the MAOAC method could be considered as an accurate, reproducible, rapid, and comparable to the AOAC method. Also, it is a less expensive, effective, less technically difficult, and more environmental friendly method compared with the AOAC starch analysis method.

\section{Funding}

This research did not receive any specific grant from funding agencies in the public, commercial, or not-for-profit sectors.

\section{Acknowledgements}

The authors express appreciation to Dr. Mary Beth Hall, USDA-Agricultural Research Service, U.S. Dairy Forage Research Center, Madison, WI for her workshop on starch analysis at South Dakota State University in January 12, 2011.

\section{References}

AOAC, 2002. Guidelines for Single Laboratory Validation of Chemical Methods for Dietary Supplements and Botanicals. Association of Official Analytical Chemists, Gaithersburg, MD.

AOAC, 2005. Official Methods of Analysis, 18th ed. Association of Official Analytical Chemists, Gaithersburg, MD.

Bach Knudsen, K.E., 1997. Carbohydrate and lignin contents of plant materials used in animal feeding. Anim. Feed Sci. Technol. 67, 319-338.

Hall, M.B., 2009. Determination of starch, including maltooligosaccharides, in animal feeds: comparison of methods and a method recommended for AOAC collaborative study. J. AOAC Int. 92, 42-49.

Karkalas, J., 1985. An improved enzymic method for the determination of native and modified starch. J. Sci. Food Agric. 36, 1019-1027.

Kelava, T., Caver, I., Culo, F., 2011. Biological actions of drug solvents. Periodicum Biologorum 113, 311-320.

McCleary, B.V., Gibson, T.S., 1989. Purification, properties, and industrial significance of transglucosidase from Aspergillus niger. Carbohydr. Res. 185, $147-162$.

McCleary, B.V., Solah, V., Gibson, T.S., 1994. Quantitative measurement of total starch in cereal flours and products. J. Cereal Sci. 20, 51-58.

McCleary, B.V., Gibson, T.S., Mugford, D.C., 1997. Measurement of total starch in cereal products by amyloglucosidase- $\alpha$-amylase method: collaborative study. J. AOAC Int. 80, 571-579.

McCleary, B.V., McNally, M., Rossiter, P., 2002. Measurement of resistant starch by enzymic digestion in starch samples and selected plant materials: collaborative study. J. AOAC Int. 85, 1103-1111.

Moreels, E., Amylum, N.V., 1987. Measurement of the starch content of commercial starches. Starch 39, 414-416.

Omi, S.K., Rose, R., 1991. Amyloglucosidase and $\alpha$-amylase enzymes for determining starch concentration in ponderosa pine root tissue. For. Sci. 37, 1479-1483.

Rose, R., Rose, C.L., Omi, S.K., Forry, K.R., Durall, D.M., Bigg, W.L., 1991. Starch determination by perchloric acid vs enzymes: evaluating the accuracy and precision of six colorimetric methods. J. Agric. Food Chem. 39, 2-11.

Shreve, B., Thiex, N., Wolf, M., 2006. NFTA Method 2.1.4 - Dry Matter by Oven Drying for 3 Hours at $105^{\circ} \mathrm{C}$. NFTA Reference Methods. National Forage Testing Association, Omaha, NE, http://www.foragetesting.org/files/NFTAReferenceMethodDM-09-18-06.pdf (accessed 16.02.02).

Takeda, K., Pokorski, M., Sato, Y., Oyamada, Y., Okada, Y., 2016. Respiratory toxicity of dimethyl sulfoxide. Adv. Exp. Med. Biol. 885, 89-96.

Windrum, P., Morris, T.C.M., 2003. Severe neurotoxicity because of dimethyl sulphoxide following peripheral blood stem cell transplantation. Bone Marrow Transplant. 31, 315. 